\title{
Web-based audiovisual phonetic table program application as e- learning of pronunciation practice in undergraduate degree program
}

\author{
Ayu Bandu Retnomurti* and Rr. Astri Indriana Octavita H. \\ English Education Department, Indraprasta PGRI University, Jakarta, Indonesia
}

\begin{abstract}
Verbal-based learning such as English pronunciation practice requires the existence of an effective e-learning because if it is directly given without any learning media, inaccuracies in pronunciation, spelling, repetition will usually occur in the spoken language. Therefore, this study aims to develop e-learning to be used in the Pronunciation Practice class, Indraprasta PGRI University. This research belongs to Research and Development are: requires an analysis, develops syllabus and teaching materials, creates and develops elearning, tries and revises the media. Consequently, there is a need to develop module in the classroom into a versatile technology web-based module in the form of Phonetic Table Program. The result is carried out in pronunciation practice classes to find more details on some parts that may still not be detected by the researchers. Thus, the use of technology has become a necessity to assist students in achieving the learning objectives. Therefore, the process of communication in learning will attract more students' interest and provide facilities to understand the sound system of English as it is equipped with buttons to practice presented by nonnative speakers. Non-native speakers' selection are based on the consideration that they quickly adapt helping other students who are less fluent in English.
\end{abstract}

\section{Introduction}

Language learning is essentially a process of learning a language. Learning a language is certainly not infallible. Khansir (2012) states everyone is not infallible in learning a language. Keep in mind that error is a source of inspiration to adjust. The study of error and its relationship to language teaching should be encouraged because it is through the study of error, various things related to language error made by students or learners can be expressed. Pronunciation Practice class in the English Department is a media which can be used to develop verbal language skills, listening and speaking. Without adequate mastery of pronunciation, it is impossible a person can speak English well. Error in pronunciation can lead to misunderstanding. In order to make someone understand us in English, we must be able to pronounce English words correctly and in order to understand English, one must be able to capture and understand the pronunciation of others. New technology, especially multimedia has an increasingly important role in learning process. Many people believe that multimedia will be able to bring us to the situation to replace learning with effort to learning with fun. Thus, fun, creative and interesting learning process will be the right choice for educators. Conventional learning system that has been applied so far (faculty of teaching) is strongly connected with instructional concept and is considered to be less suitable to the enthusiasm of rapid development of science and technology. Conventional learning system is less flexible in accommodating the competency of materials development because educators should intensively adjust the teaching materials with the latest technological developments. In fact, at present, Indonesia is entering the information age, an age which is characterized with rapid increase of information medium. The spread of information will always use media, either electronic or non-electronic one. The explanation above shows that the presence of the media has influenced the whole aspects of life including our education system, although in a varying degree. Students should have the skills to read the sound symbols used in the dictionaries so that if once they find a new word whose pronunciation is unknown they will be able to consult the dictionary. But the reality is not always so. On many occasions, even in the undergraduate thesis examination, it is quite common to find students who mispronounced words, even words that are often used in everyday communication and learning. Even worse, if they are asked to check into a dictionary, they will not be able to read the symbols with the right sound. This fact shows that learning Pronunciation Practice has not been managed optimally and will leave negative impact on the mastery of English as a whole, especially in spoken language. Students are the major components in determining the learning outcomes because they are the subject of learning activities. Students with proper prior ability are quite likely to be easier to accept and process teaching materials and training compared to students with

\footnotetext{
* Corresponding author: ayubandu@gmail.com
} 
lower prior ability. Initial capability is also influential in other learning components, such as the determination of the syllabus, the level of difficulty of teaching materials, teaching techniques and a variety of exercises (Riswanto \& Endang, 2012: 9).

Based on previous observation, proper learning outcomes of pronunciation practice can only be achieved by students who have had adequate prior knowledge enough, while students with lower initial ability result in less satisfactory results (Nilsen, 2002: 89). The role of lecturers in Pronunciation Practice learning is as a manager, as a motivator, a facilitator and a model. Pronunciation Practice lecturers should be able to devise proper teaching and learning activities, select appropriate materials, assist students in training, monitor exercises and learning progress of students, and should also be an example or model of how to pronounce English properly (Yulia and Ouda: 2004). The lecture that has been implemented so far is centered on the lecturer. Student activities in class seem to be monotonous and unattractive. Learning activities are focused only on the student handbook. Students are only required to imitate lecturers individually after finding or writing the proper pronunciation through the dictionary. Consequently, in pronunciation practice, students are still unconfident to apply the correct pronunciation like a native in an English conversation. The correct pronunciation will sound strange and funny when practiced by students who are reluctant to apply the aspects of correct pronunciation.

Based on the background of the problems described above, it expects the presence of design concept development through PROTATIK audio-visual (PROTATIK means in Indonesian Program Tabel Fonetik) web-based e-learning as solution to effective Pronunciation Practice in college, so it gives good results on pronunciation skills of the students.

\section{Method}

To produce learning media suitable for use and requirement, a research approach and development need to be taken. Research and development are methods to develop and test a product. According to Sadiman (2005: 64) in his book entitled "Learning Media for Education" which is in the field of education, research and production/development can be used to develop books, modules, instructional media, evaluation instruments, models of curriculum, learning, evaluation and other other. According to him, there are three steps of research and development, namely: 1) conduct a preliminary study to examine the theory and supervise the product or activity, 2) develop a product or a new activity program, and 3 ) test or validate a product or a new activity program. The first step has been carried out, a preliminary study by reviewing the theories which are included in the literature review about the creation of media and media content that will be developed. Whereas, the development of Pronunciation Practice learning media takes some steps: 1) conduct an analysis on needs, 2) develop syllabus, lessons and training, 3) create a learning media in the form of web-based audio-visual Phonetic Table Program, and
4) conduct a test and improve learning media. Research data are taken from lecturers and students of the Pronunciation Practice classes of Indraprasta University PGRI Jakarta. Data are in the form of qualitative data, on opinions and suggestions from both lecturers and students which are collected in peer discussion, class of observation, and questionnaires. According to Sadiman (2005: 68) there are three steps of research and development in general, i.e.: : 1) conduct a preliminary study to examine the theory and supervise the product or activity, 2) develop a product or a new activity program, and 3 ) test or validate a product or a new activity program. The first step has been carried out, a preliminary study by reviewing the theories which are included in the literature review about the creation of media and media content that will be developed. Whereas, the development of Pronunciation Practice learning media takes some steps: 1) conduct an analysis on needs, 2) develop syllabus, lessons and training, 3) create a learning media in the form of web-based audio-visual Phonetic Table Program, and 4) conduct a test and improve learning media. The instruments in this research include: records of implementation and questionnaire. Next, data are discussed with colleagues and students, classroom observation, and questionnaires which are analyzed in qualitative descriptive manner and are directly applied to the development and improvement of learning media in the Pronunciation Practice course.

\section{Results and output achieved}

The result of this research is an application of web- based Pronunciation Practice audiovisual Phonetic Table Program, e-learning media that contains a table presenting the pronunciation of consonants and vowels in English which can be heard and are equipped with buttons exercises to practice. The followings are the process of the design and development process of the learning media. The development of audiovisual Phonetic Table Program, a learning media for Pronunciation Practice takes the following steps: 1) the analysis of needs, 2) the development of the syllabus and the preparation of materials and training materials, 3 ) the creation of the media, 4) the test and repair on the media (Sadiman, 2005: 64).

\subsection{Analysis of Needs}

In order to recognize the suitable media needed in learning Pronunciation Practice in English Education study program, Faculty of Language and Art, UNINDRA PGRI, the research team deliberates on pronunciation practice class learning that has been practiced. The results of this deliberation are discussed in teams of lecturers who teach Pronunciation Practice classes to get extra practice and validation of data on current issues in the Pronunciation Practice class and the media needed to overcome the existing problems. Pronunciation Practice teaching so far has not given any satisfactory result as shown by many facts. First, student results on exams are less satisfying. Students can imitate any given sounds or 
words by the lecturer in class, but they immediately forget about it. The research team realizes that they need the latest pronunciation practice model that they can listen to and imitate whenever or wherever they need. At present, manual of pronunciation practice model is provided directly by the lecturers while teaching in the classroom without being accompanied by recordings. Lecturers have to shout repeating the same words, phrases, and sentences from class to class. To solve this problem, a good lecture module is indispensable. Class teaching material of Pronunciation Practice in English Department is a handbook lecture entitled Teaching to Mastery: PRONUNCIATION PRACTICE: (Purwanto Andri, Retnomurti Ayu \& Mutiara Dewi, 2016) This module/UNINDRA handbook contains all the lecture materials and is accompanied by adequate practice materials. Unfortunately, this module is not accompanied by recording of speech models or practices that are required by both lecturers and students. From this point of view, it is acceptable to say that we need a lecture module that is accompanied by a recording of acceptable speech models. Making recording materials to assist the existing module is feasible to improve the quality of learning Pronunciation Practice, so that the medium of instruction not only in the form of modules but also tables of phonetic sounds in English and Phonetic Table Program, a recording material for practice or exercise that will facilitate the work of lecturers in delivering speech model to be used by students to learn at home. However, when considering the progress of IT today, teaching to use the manual module perhaps is not so interesting anymore. It is time the researchers develop existing manual module to be an effective technology-based module, a Phonetic Table Program in the form of cutting-edge media to make Pronunciation Practice teaching more attractive as it uses web-based technology. Results of observation on the Pronunciation Practice teaching in English Department is taken to the discussion forum of Pronunciation Practice lecturers to generate comments, insights and clarity on media that is actually needed. Here are the results of these discussions: The lecturers generally face similar problems in the teaching of Pronunciation Practice, so all agreed that what is needed is a lecture material that has been arranged systematically accompanied by a number of exercises, recording materials, exercises or practices that can be used in Pronunciation Practice teaching in the classroom. A lecturer confirms that it doesn't have to be a sophisticated media, modules and cassettes shall be enough. But there is also opinions saying we should keep up with technology, so there is no harm if this media is made to be computer-based to optimize the learning process. The materials must be included in this media covers a phonetic table of English sounds. While the materials of exercises or practices should cover loose the words, groups of words, texts, and sentences of various forms, dialogs, or paragraphs.

\subsection{Syllabus, Lecture Material and Practice or Exercise Materials}

Syllabus or Unit Course Events is based on course descriptions of Pronunciation Practice Curriculum in English Education, Faculty of Language and Art, University of Indraprasta PGRI 2015/2016, the purpose of learning and teaching material scope of UNINDRA Pronunciation Practice Handbook (2016) and Hancock (2003): English Pronunciation in Use; Self Study and Classroom Use and the results of the discussion among colleagues who teach Pronunciation Practice on need analysis. Practice or training materials are developed in accordance with the lecture material added with other exercises for the development of the required skill which include the pronunciation of loose words, groups of words, texts, sentences, paragraphs and dialogues. This course syllabus includes four components: 1) The topic of learning, 2) learning objectives, 3) learning materials, and 4) practices or exercises.

Table 1: Syllabus / Pronunciation Practice SAP

\begin{tabular}{|c|c|c|c|}
\hline Topic & Purpose & Material Description & Practice or Exercise \\
\hline 1.Introduction & $\begin{array}{l}\text { Students Have an overall } \\
\text { picture of the contents of } \\
\text { the Pronunciation Practice } \\
\text { lecture }\end{array}$ & $\begin{array}{l}\text { Definition of Pronunciation } \\
\text { Table of English sounds } \\
\text { Letters and sounds }\end{array}$ & $\begin{array}{l}\text { Loose words (regular, irregular } \\
\text { verbs, plural forms), phrases, texts, } \\
\text { sentences of various forms, } \\
\text { paragraphs, and dialogues }\end{array}$ \\
\hline 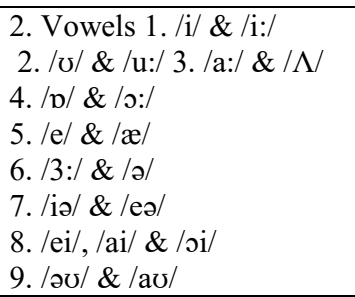 & $\begin{array}{l}\text { 1, Students can pronounce } \\
\text { English vowel sounds } \\
\text { 2. Students can produce } \\
\text { English vowel sounds }\end{array}$ & The Vowel sounds & $\begin{array}{l}\text { Loose words of all English vowel } \\
\text { sounds considered difficult for the } \\
\text { students. }\end{array}$ \\
\hline $\begin{array}{l}\text { 3. Consonants: } 10 . / \mathrm{p} / \& / \mathrm{b} / \\
11 . / \mathrm{t} / \& / \mathrm{d} / \\
12 . / \mathrm{k} / \& / \mathrm{g} \\
13 . / \mathrm{v} / \& / \mathrm{f} / \\
14 . / \Theta / \& / \mathrm{d} / \\
15 . / \mathrm{s} / \& / \mathrm{z} / \\
16 . / \mathrm{J} / \& / \mathrm{Z} / \\
17 . / \mathrm{t} / \& / \mathrm{d} /\end{array}$ & $\begin{array}{l}\text { 1. Students have an } \\
\text { overview of the English } \\
\text { consonant sounds } \\
\text { 2. Students can pronounce } \\
\text { examples of consonant } \\
\text { sounds in words correctly } \\
\text { without consulting the } \\
\text { dictionary }\end{array}$ & $\begin{array}{l}\text { The consonant sound and a } \\
\text { summary in table form } \\
\text { Consonant sounds of words } \\
\text { with words }\end{array}$ & Loose words with consonant sounds \\
\hline
\end{tabular}




\begin{tabular}{|c|c|c|c|}
\hline $\begin{array}{l}18 . / \mathrm{m} /, / \mathrm{n} / \& / \mathrm{y} / \\
19 . / \mathrm{h} /, / 1 / \& / \mathrm{r} / \\
20 . / \mathrm{w} / \text { and } / \mathrm{j} /\end{array}$ & & & \\
\hline $\begin{array}{l}\text { 4. -Syllables } \\
\text {-Words }\end{array}$ & $\begin{array}{l}\text { 1. The student can } \\
\text { distinguish the differences } \\
\text { between syllables and } \\
\text { words } \\
\text { 2. Students can pronounce } \\
\text { syllables and words with } \\
\text { different stress } \\
\text { 3. The students can } \\
\text { determine the number of } \\
\text { syllables of each word in a } \\
\text { phrase or a sentence } \\
4 \text {. The students can } \\
\text { pronounce syllables, } \\
\text { words, phrases or } \\
\text { sentences correctly }\end{array}$ & $\begin{array}{l}\text { Introduction to syllables } \\
\text { Consonants at the start of } \\
\text { syllables } \\
\text { Consonants at the end of } \\
\text { syllables } \\
\text { Syllables: plural and other -s } \\
\text { endings } \\
\text { Syllables: adding past tense } \\
\text { endings } \\
\text { Introduction to word stress } \\
\text { Stress in two-syllable words } \\
\text { Stress in compound words } \\
\text { Stress in longer words } 1 \\
\text { Stress in longer words } 2\end{array}$ & $\begin{array}{l}\text { Loose words: verbs and nouns, } \\
\text { words begins with a consonant in the } \\
\text { initial of syllables, final of syllables, } \\
\text { plural syllable, suffix -s, past tense } \\
\text { suffixes, word stress, plural words, } \\
\text { and complex sentences and } \\
\text { compound sentences. }\end{array}$ \\
\hline $\begin{array}{l}\text { 5. Sentences (part I) } \\
\text { Sentences (part II) } \\
\text { Sentences (part III) }\end{array}$ & $\begin{array}{l}\text { Students can pronounce } \\
\text { phrases, sentences, texts } \\
\text { and dialogues properly } \\
\text { and smoothly }\end{array}$ & $\begin{array}{l}\text { Introduction to sentence stress } \\
\text { Sentences with all the words } \\
\text { stressed } \\
\text { Unstressed words } \\
\text { Pronouns and contractions } \\
\text { Pronouncing the verb be } \\
\text { Auxiliary verbs } \\
\text { Pronouncing short words (a, } \\
\text { of, or) } \\
\text { Joining words } 1 \\
\text { Joining words } 2 \\
\text { Joining words } 3\end{array}$ & $\begin{array}{l}\text { Examples of sentences that contain } \\
\text { elements of stress / unstressed in the } \\
\text { sentence, pronouns, auxiliary verbs, } \\
\text { and article }\end{array}$ \\
\hline
\end{tabular}

\subsection{Media Making}

Lecture and practice or exercise materials by speaker/nonnative speaker models which have been organized are made into an application form (web-based audio-visual Phonetic Table Program). This e-learning is created using the PHP program, Java Script, Jquery and CSS. Macromedia Dreamweaver and Adobe Photoshop are also used. The application development is divided into several stages: analysis, program design, testing and evaluation. The materials developed in the previous step are analyzed, designed and typed in Microsoft Word program because if the materials are typed directly on the program PHP, Java Script, Jquery or CSS, the materials would be too long and very difficult to edit. After all the analyzed material is completed, the next step is to copy the material into the PHP, Java Script, Jquery and CSS program. Next, each of PHP page is equipped with the desired command, namely, forward or return to previous page, play and stop the sound, to the other files, and call the sound symbol table. The next process is recording the non-native speakers. Sound recordings are used to fill the key icon practice contained in this Phonetic Table Program application. The sound is recorded from the models, lecturers from English Department Faculty who pass the selection. Sound is recorded using Macromedia Dreamweaver and Adobe Photoshop with Windows Media Player from Microsoft. After recording the voice, the voice file is then stored in WAV format, MP3, and then edited to suit low high, volume, and to eliminate existing noise. Edited sound file is then connected to a PHP file that has been inserted with commands. After each page is linked to a sound file, the next processes are conducting a trial and then checking each page. This process is done to look at the suitability of a given command with the desired results. This trial is necessary because after checking, it turns out there are many commands that do not run or do not correspond to the desired result. Once the file is tested, then the researchers repair the application. In this mater, the research team uses non-native speakers sound for teaching and learning in the classroom according to the agreement between the lecturers of Pronunciation Practice class. In order to achieve the teaching target in the classroom, the exercises of the pronunciation practice use non-native speakers from their colleagues who have passed the selection. The reason behind the selection is that "Native speakers are usually monolingual and are not versatile enough in adjusting themselves to many different languages" as stated by Jenkins, a professor of global language-English at the University of Southampton in England. She adds, it turns out those who are non-native speakers tend to speak more regularly and carefully, typical of someone who speaks a second or third language. On the other hand, English speakers / native speakers, often talk too fast to be followed by others, and use jokes, slang language and refer to specific things of their own culture. Non-nativespeakers typically use a more limited vocabulary and phrases that are simpler, without figurative language or slang. Therefore, they understand each other through facial gestures. After finishing the media making, the last step is tests and repairs on the media. 


\subsection{Tests and repairs on the media}

Web-based Phonetic Table Program e-learning media application that has been developed is then tested for learning in the classroom. The test is done in pronunciation practice classes to find out more details on some parts that may still not be detected by the research team. This process is also very necessary to get suggestions from students. The test involves Pronunciation Practice classes (R2A and R2B) such as they are required to give comments on Phonetic Table Program that they have just used. Their comments include three variables, the advantages and disadvantages of the media as well as suggestions for improvement.

Table 2. Comment on test media students in the first year

\begin{tabular}{|c|c|c|}
\hline No & Comments & $\begin{array}{l}\text { Frequency of } \\
\text { students }\end{array}$ \\
\hline \multirow[t]{10}{*}{1} & Excess of the media: & \\
\hline & $\begin{array}{l}\text { 1. Very useful for students in } \\
\text { learning Pronunciation Practice } \\
\text { in the classroom }\end{array}$ & 17 \\
\hline & 2. Easy to operate by user & 11 \\
\hline & $\begin{array}{l}\text { 3. Relatively clear English } \\
\text { symbol sounds }\end{array}$ & 6 \\
\hline & $\begin{array}{l}\text { 4. Contains relatively complete } \\
\text { exercises and practices }\end{array}$ & 5 \\
\hline & $\begin{array}{l}\text { 5. Help students in individual } \\
\text { practices }\end{array}$ & 2 \\
\hline & $\begin{array}{l}\text { 6.Flexibel, students can choose } \\
\text { their } \\
\text { materials/exercises }\end{array}$ & 2 \\
\hline & 7. Attractive design & 2 \\
\hline & $\begin{array}{l}\text { 8. non-native speakers by lecturer } \\
\text { sounds clear }\end{array}$ & 1 \\
\hline & $\begin{array}{lrr}9 . \quad \text { Recording sound } & \text { of } \\
\text { PROTATIK is clear } & \end{array}$ & 1 \\
\hline \multirow[t]{5}{*}{2} & Weaknesses of the media: & \\
\hline & $\begin{array}{l}1 \text { Packaging is not attractive } \\
\text { enough }\end{array}$ & 5 \\
\hline & $\begin{array}{l}2 \text { Cannot be used if the students } \\
\text { do not have computers }\end{array}$ & 2 \\
\hline & $\begin{array}{l}\text { 3. Less practical, because } \\
\text { students must click many icons }\end{array}$ & 1 \\
\hline & $\begin{array}{l}\text { 4. Lack of exercise in the form of } \\
\text { poems or texts of songs in order } \\
\text { to check whether our vocabulary } \\
\text { is already correct }\end{array}$ & 4 \\
\hline \multirow[t]{9}{*}{3} & suggestions for improvement: & \\
\hline & 1. Fix existing errors & 4 \\
\hline & 2. Add animation & 3 \\
\hline & 3. Make slower pace & 2 \\
\hline & $\begin{array}{l}\text { 4. Add music in the middle of the } \\
\text { program }\end{array}$ & 1 \\
\hline & 5. Add more examples & 1 \\
\hline & 6. soften the color & 1 \\
\hline & 7. brighten the colors & 1 \\
\hline & $\begin{array}{l}\text { 8. make the web-based software } \\
\text { application PROTATIK free for } \\
\text { students }\end{array}$ & 1 \\
\hline
\end{tabular}

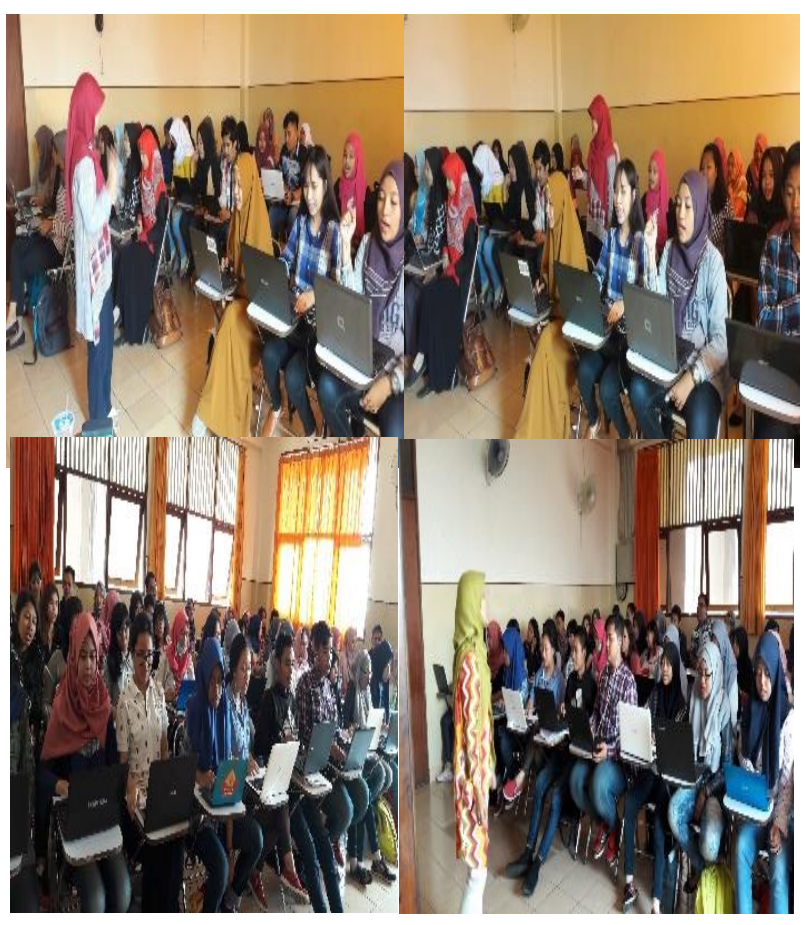

Fig 1. Documentation in R2A \& R2B classrooms
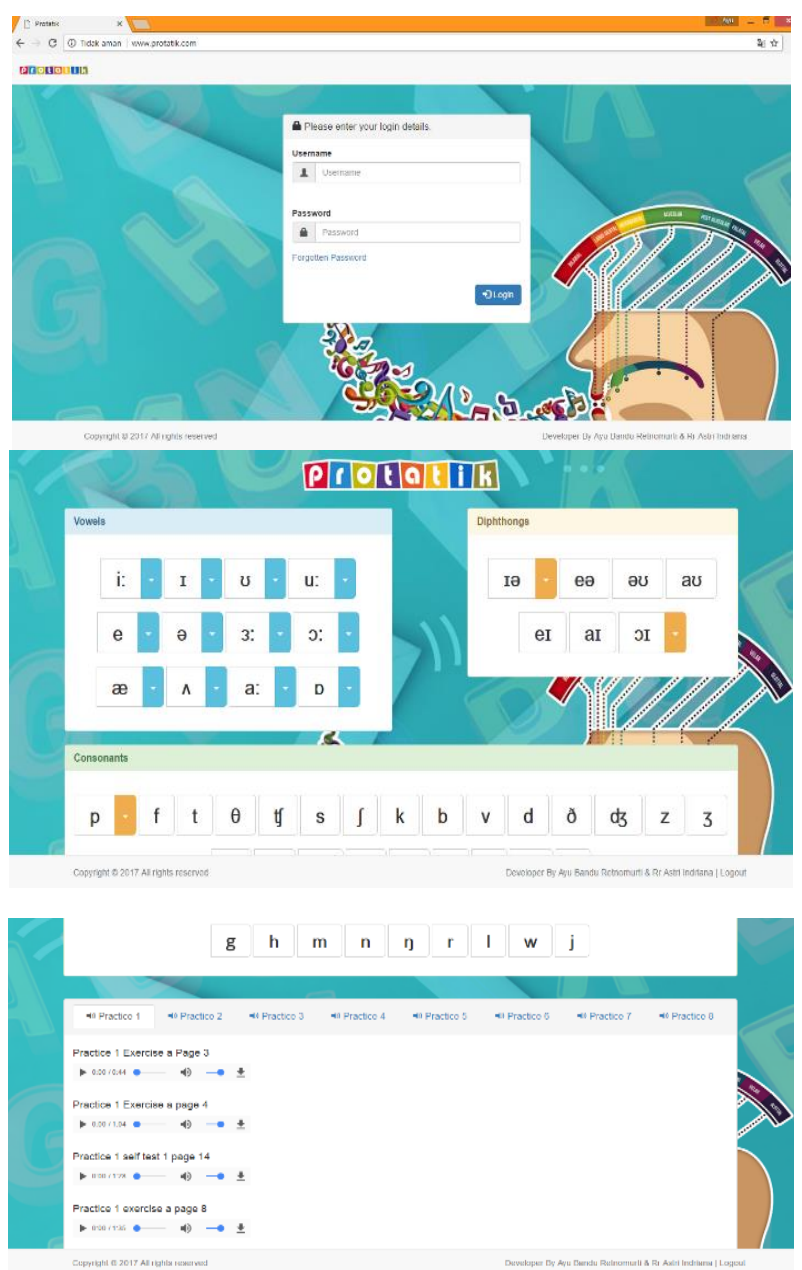

Fig 2. Display of web-based PROTATIK e-learning in http://www.protatik.com/ 


\section{Conclusion}

After developing the web-based Phonetic Table Program learning media and conducting development tests in the first year of use of the media in learning Pronunciation Practice in the class by giving comments include three variables, the advantages and disadvantages of the media as well as suggestions for improvement, the researchers can conclude several things, namely:

1. The process of development of the learning media is an interdisciplinary field. Here synergic cooperation between lecturers who master the field of science and teaching, and those skilled in the technical field of making the media, the master computer programs or information technology and also understand the teaching field to be developed is greatly required. In addition, the research team uses the voice of non-native speakers / lecturers of Pronunciation Practice for the voice, in this case the person reading lessons. Peer selection is made between lecturers who do not only have good voice, but also have the ability to say near-perfect English.

2. The contents of the web-based Phonetic Table Program learning media are taken from available sources, both text and voice recording. These sources belonging to other people, thus this Phonetic Table Program learning media which is still developed is not for sell both to students and the research institutions, before its intellectual property right being formally certified. This web-based Phonetic Table Program learning media is temporary only used for a limited group, namely teaching Pronunciation Practice in English Department, Language and Art faculty, Indraprasta PGRI Jakarta University in the first year. This media which is still in its development process is in the form of a web-based application Program of Phonetics Table. Therefore, in the teaching process, the application needs to be assisted with specific facility, for example the language laboratory, computer laboratory, or classrooms equipped with computers, LCD, and speakers. For students who want to use Flash Disk or network for independent study at home, they should have at least a computer / laptop / notebook at home. Although the use of the media requires certain conditions, namely their computer / laptop / notebook, the media is quite effective in facilitating Pronunciation Practice lecturers and students in the learning process. Lecturer in the class gets the ease of delivering the material and gives the correct speech model.

The researchers' team would like to thank profusely to the Indonesia Government through Appreciation and gratitude to Directorate of Research and Community Service, Directorate General of Research and Development, Ministry of Research, Technology and Higher Education who has financed national competitive research activities Applicable Product Research (PPT) Year 2017 entitled: Rancang Bangun melalui Audiovisual TATIK (Program Tabel Fonetik) Berbasis Website sebagai Media Pembelajaran Pronunciation Practice pada Program Sarjana ". Thanks also to Kopertis Wilayah III Jakarta and Institute for Research and Community Service of Indraprasta PGRI University who has assisted this research activity KEMENRISTEKDIKTI as the organizer of funds at the expense of Applied Research Products, LP2M UNINDRA and Indraprasta PGRI Jakarta University as institutions that facilitate and support the progress and success of this research through Research Contract 0428/K3/KM/2017, Date May 24, 2017. And UNINDRA Research Agreement/Contract Number: 0552/SKP.LT/LPPM/UNINDRA/VI/2017, Date June 05, 2017. Finally, the researchers' team also would like to thank to the second ICET4SD Yogyakarta \& MATEC Web Conferences for our publication committee.

\section{References}

1. A, A, Khansir, Error analysis and second language acquisition, Theory and practice in language studies, 2(5), 1027 (2012)

2. Andri, Purwanto, Ayu B, Retnomurti. Dewi, Mutiara, Indah A, Teaching to Master Pronunciation PracticeA Pronunciation Teaching Learning Tool-An Effective Pronunciation-Teaching Learning Strategy, UNINDRA. (2016)

3. A, Sadiman, Media Pendidikan, Jakarta. PT Raja Grafindo Perkasa (2005)

4. Don, L.F Nilsen. Pace, Nilsen Alleen. Pronunciation Contrast in English, Pearson Education Inc, Waveland Illinois USA. (2002)

5. Mark, Hancock, English Pronunciation in Use; Self Study and Classroom Use, Cambridge: Cambridge University Press. A. 80 (2003)

6. M.F, Yulia, Ena Teda Ouda, "Pronunciation Problems of Indonesians EFL Teachers", the Proceeding of the 9th Eng. in South. Asia Conf. USD. Yogyakarta (2004)

7. Riswanto, Endang Haryanto, 'Improving Students' Pronunciation through Communicative Drilling Technique at Senior High School (SMA) 07 South Bengkulu, Indonesia", International Journal of Humanities and Social Science, 2 (21), 10 (2012) 